Syntax Fusion : Jurnal Nasional Indonesia

p-ISSN: -

e-ISSN : $2775-4440$

Vol. 1, No. 8, Agustus 2021

\title{
PENGARUH KESADARAN MEREK DAN KUALITAS PRODUK TERHADAP KEPUASAN KONSUMEN (STUDI PADA TOKO BUSANA MUSLIM VENKA GALLERY BANDA ACEH)
}

\author{
Yusniar, Hafidhah dan Nada Fitria \\ STAI Tgk. Chik Pante Kulu Banda Aceh, Indonesia \\ Universitas Islam Negeri Ar-Raniry Banda Aceh, Indonesia \\ Email: yusniarmyusufibrahim@gmail.com,
}

\begin{abstract}
Abstrak
Penelitian ini bertujuan untuk mengetahui apakah terdapat pengaruh kesadaran merek dan kualitas produk terhadap kepuasan konsumen pada toko busana muslimi Venka Gallery Banda Aceh. Penelitian ini merupakan penelitian kuantitatif, dimana sampel yang diambil sebanyak 100 responden yaitu seluruh konsumen toko Venka Gallery Banda Aceh dengan menggunakan teknik purposive sampling. Jenis data yang digunakan adalah data primer yaitu mengedarkan kuesioner melalui google form. Metode analisis penelitian dilakukan dengan menggunakan regresi linear berganda. Penelitian menemukan bahwa kesadaran merek dan kualitas produk secara simultan dan parsiall berpengaruh positif dan signifikan terhadap kepuasan konsumen. Berdasarkan uji $R 2$ pengaruh yang diberikan oleh variabel independen terhadap variabel dependen sebesar 36,0 \% sedangkan sisanya 64,0 $\%$ dipengaruhi oleh variabel lain yang tidak disertakan dalam penelitian ini.
\end{abstract}

Kata kunci: Kepuasan Konsumen, Kualitas Produk, Merek

\section{Pendahuluan}

Perkembangan teknologi dan industri membawa dampak bagi kehidupan manusia terutama pada dunia bisnis saat ini. Era sekarang persaingan antar bisnis semakin tinggi, diikuti dengan bertambahnya jumlah pemain bisnis dalam menawarkan produk yang sama. Munculnya persaingan bisnis yang semakin ketat, maka perusahaan harus dapat berkembang dan bertahan hidup agar tidak kalah dengan pesaingnya. Bisnis busana muslim adalah salah satu terobosan baru dalam bisnis fashion, selain itu bisnis dibidang busana muslim telah menjadi fenomena trend tersendiri di tanah air dan menjadi salah satu bisnis yang cukup menjanjikan. Bisnis busana muslim semakin berkembang menyesuaikan perkembangan mode yang menjadikan busana muslim saat ini memiliki model yang beragam serta penggunaan warna dan bahan yang bervariatif 
mampu menjadikan busana muslim sebagai trendsetter di dunia fashion. Busana muslim yang fashionable merupakan pilihan yang tepat bagi wanita yang ingin tampil menarik namun tidak mengesampingkan aturan busana sesuai dengan syariat Islam. Biasanya, para wanita muslimah menggunakan gamis dan juga hijab jika berpergian keluar rumah. Pakaian yang digunakan tentunya juga harus sesuai dengan syari'at Islam yaitu tidak tipis, tidak menerawang dan tidak ketat.

Banda Aceh merupakan salah satu kota dengan mayoritas penduduknya beragama Islam. Penduduk yang beragama Islam baik perempuan maupun laki-laki diwajibkan untuk memakai busana yang sesuai dengan ajaran Islam yaitu busana yang mampu menutup aurat, seperti tidak membentuk tubuh, tidak tipis, tidak ketat, tidak menerawang dan tidak menyerupai lawan jenis, karena di dalam Islam menutup aurat merupakan kewajiban bagi setiap muslim agar terhindar dari hal-hal yang mengandung mudharat. Saat ini di Banda Aceh terdapat beberapa perusahaan yang bergerak dibidang fashion busana muslim dikarenakan busana muslim sudah menjadi pakaian sehari-hari bagi masyakarat Banda Aceh, oleh karena itu setiap perusahaan harus lebih unggul dalam memasarkan produknya demi terciptanya kepuasan dalam diri konsumen mengingat banyaknya pesaing yang bergerak dibidang bisnis yang sejenis.

Kepuasan yang dialami konsumen akan memberikan citra yang baik bagi perusahaan sehingga akan ada kemungkinan konsumen melakukan pembelian ulang terhadap suatu produk. Maka dari itu, penting bagi suatu perusahaan untuk meningkatkan kepuasan konsumen guna untuk mempertahankan pelanggan yang ada atau menarik pelanggan baru. Sunarto (2006:7) menyatakan bahwa kepuasan konsumen adalah perasaan senang atau kecewa seseorang yang muncul setelah membandingkan antara persepsi/kesannya terhadap kinerja suatu produk dan harapan-harapannya. Disimpulkan bahwa kepuasan pelanggan yaitu perasaan puas yang dirasakan pelanggan saat membeli ataupun menggunakan suatu produk maupun jasa tertentu.

Menurut ekonomi Islam konsumen dalam memenuhi kepuasan atau kebutuhannya cenderung untuk memilih barang dan jasa yang memberikan mashlahah maksimum. Kecenderungan memilih ditentukan oleh kebutuhan dan keinginan. Berdasarkan analisa tersebut ditarik suatu pengertian bahwa kepuasan konsumen menurut ekonomi Islam berkaitan erat dengan kebutuhan, keinginan, mashlahah, manfaat, berkah, keyakinan dan kehalalan (Pusat Pengkajian dan Pengembangan Ekonomi Islam P3EI UII, 2008).

Kesadaran merek merupakan salah satu faktor yang dapat mempengaruhi kepuasan konsumen. Kesadaran merek penting bagi kelangsungan suatu produk dapat diterima atau tidaknya produk tersebut dikalangan masyarakat, meskipun suatu produk bagus namun apabila konsumen tidak mengenali bahkan tidak pernah mendengar merek tersebut maka mereka tidak akan membelinya. Merek dalam suatu produk sangatlah penting untuk membedakan satu produk dengan produk lainnya, merek juga menjadi elemen penting bagi suatu perusahaan demi untuk mencapai kesuksesan pemasaran yang baik.

Selain merek, kualitas dari suatu produk juga tak kalah penting dan perusahaan 
dituntut untuk menghasilkan produk yang inovatif dan kreatif dalam menciptakan produk-produk agar mempunyai kualitas terbaik serta sesuai dengan biaya yang dikeluarkan konsumen untuk mendapatkan produk tersebut, mengingat kebutuhan konsumen semakin berkembang dan selera konsumen yang berubah. Assauri (2013:12) mendefinisikan kualitas produk adalah faktor-faktor yang terdapat dalam suatu barang atau hasil yang menyebabkan barang atau hasil tersebut sesuai dengan tujuan untuk apa barang atau hasil itu dimaksudkan. Produk yang mempunyai kualitas yang tinggi tentunya lebih dikenal oleh masyarakat dan konsumen akan membeli produk yang menurutnya memiliki kualitas yang baik.

Di Banda Aceh sudah banyak toko yang bergerak dibidang bisnis busana muslim, salah satunya adalah toko Venka Gallery yang berlokasi di Jl. Sri Ratu Syafiatuddin No. 39 A, Peunayong, Kec. Kuta Alam, Kota Banda Aceh. Toko Venka Gallery merupakan toko yang berdiri pada tanggal 12 Mei 2018. Toko Venka Gallery ini memiliki tempat yang strategis dan mudah dijangkau oleh masyarakat karena toko ini terletak di pusat kota dan memudahkan masyarakat Banda Aceh dalam berbelanja kebutuhan busana muslim. Dalam penelitian ini diangkat tema tentang kepuasan konsumen karena banyaknya merek dengan produk yang sejenis seperti Rabbani dan Zoya membuat merek Venka ini harus lebih unggul dalam memasarkan produknya. Meskipun toko Venka ini baru di buka pada bulan Mei 2018, namun mampu bersaing dengan toko dari produk sejenis yaitu Rabbani dan Zoya yang lebih awal masuk di Banda Aceh, dibuktikan dengan banyaknya peminat terhadap produk Venka ini dan ramai akan pengunjung setiap harinya serta berdasarkan hasil wawancara awal toko Venka memiliki penghasilan yang tergolong tinggi setiap bulannya. Produk Venka ini bisa menjadi pilihan bagi masyarakat yang ingin tampil menarik dengan desain yang simpel serta harga yang terjangkau dan tetap mengikuti trend busana muslim yang sedang berkembang saat ini, namun tidak mengesampingkan aturan busana yang sesuai dengan syariat Islam. Berikut adalah penghasilan toko Venka dari periode Juni 2018 - Juni 2019 dapat dilihat pada Gambar 1.

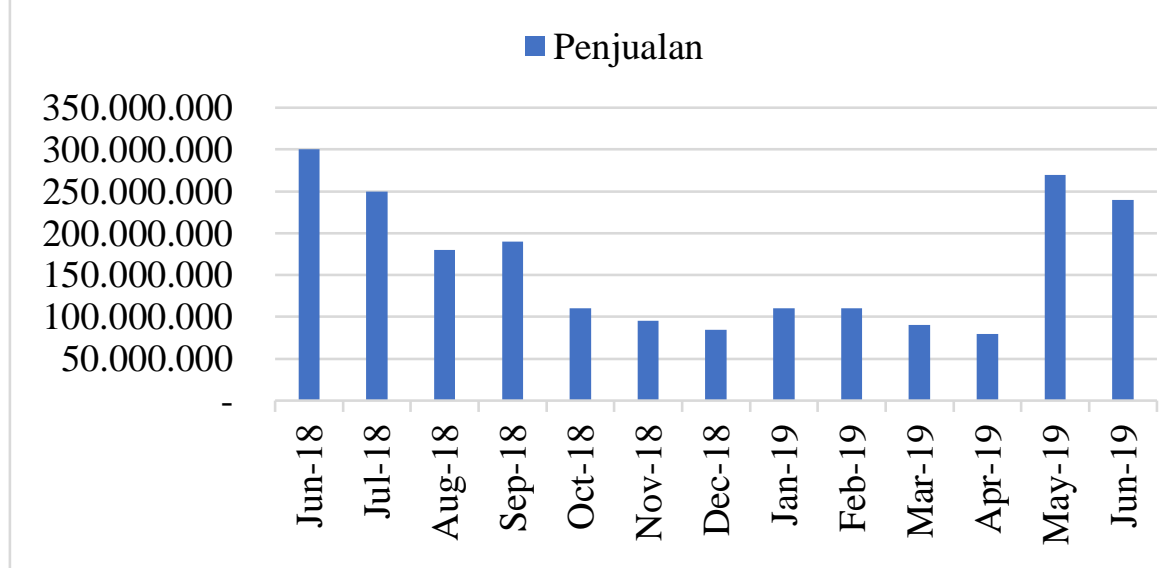

Gambar 1 Penjualan Toko Venka Gallery

Gambar 1 merupakan penghasilan toko Venka Gallery Banda Aceh pada bulan Juni 2018 hingga bulan Juni 2019. Toko Venka Gallery Banda Aceh memiliki 
penghasilan yang bervariasi setiap bulannya, mulai dari yang tertinggi hingga terendah. Penghasilan tertinggi Venka Gallery pada bulan Juni 2018 sebesar Rp 300.000.000, sedangkan terendah pada bulan April 2019 sebesar Rp 80.000.000. Pada bulan Juni 2018 hingga bulan Juni 2019 toko Venka Gallery Banda Aceh mendapatkan penghasilan keseluruhannya sebesar Rp 2.110.000.000. Maka oleh karena itu, dalam penelitian ini penulis tertarik untuk melihat faktor apa saja yang dapat mempengaruhinya. Penelitian mengenai kepuasan konsumen sudah banyak dilakukan oleh penelitian sebelumnya dengan menggunakan faktor-faktor penentu kepuasan konsumen lainnya, namun tidak mudah untuk mengangkat semua faktor-faktor tersebut.

\section{Metode Penelitian}

Penelitian ini menggunakan jenis penelitian kuantitatif. Populasi dalam penelitian ini adalah seluruh konsumen yang membeli produk di toko Venka Gallery Banda Aceh. Sampel adalah bagian dari jumlah dan karakteristik yang dimiliki oleh populasi tersebut, namun populasi sangat besar jumlahnya dan peneliti tidak mungkin mempelajari semua yang ada pada populasi karena keterbatasan dana, tenaga dan waktu, maka peneliti dapat menggunakan sampel yang diambil dari populasi tersebut.

Teknik pengambilan sampel yang digunakan dalam penelitian ini menggunakan teknik sampling yaitu nonprobability sampling, dimana setiap anggota populasi tidak memiliki kesempatan atau peluang yang sama sebagai sampel (Noor, 2011: 151). Penentuan jumlah sampel responden didasarkan pernyataan Supranto (2012: 55), yang menyatakan bahwa ukuran sampel yang baik ditentukan dengan cara jumlah pertanyaan dalam kuesioner dikali lima (5) sampai sepuluh (10). Maka penentuan jumlah sampel dalam penelitian ini, perhitungannya adalah 15 pertanyaan x $5=75$, peneliti membulatkan sampel yang digunakan dalam penelitian ini, yaitu sebanyak 100 sampel dengan menggunakan teknik purposive sampling. Sugiyono (2018:85) mengatakan purposive sampling adalah teknik penentuan sampel dengan pertimbangan tertentu yang bertujuan agar data yang diperoleh nantinya dapat lebih akurat dan representif. Adapun kriteria responden yang ditetapkan dalam penelitian ini yaitu:

1. Telah melakukan pembelian sebanyak 2-3 kali pada toko Venka Gallery Banda Aceh.

2. Laki-laki dan perempuan berusia minimal 20 tahun sampai dengan $>40$ tahun.

Pengumpulan data dilakukan dengan mengedarkan kuesioner yang berisi pernyataan-pernyataan yang berhubungan dengan kesadaran merek, kualitas produk dan kepuasan konsumen. Masing-masing pernyataan disediakan alternatif pilihan jawaban dalam bentuk tingkat kesetujuan yang diberikan skor menurut skala Likert 1-5. Responden diminta untuk memberikan respon terhadap masing-masing pernyataan terkait dengan memilih salah satu alternatif pilihan jawaban yang paling cocok. Metode analisis penelitian dilakukan dengan menggunakan regresi linear berganda. 


\section{Hasil dan Pembahasan Hasil Uji Validitas}

Ghozali (2013: 52) mengatakan bahwa uji validitas dilakukan untuk mengukur sah atau validnya suatu kuesioner sehingga dapat sesuai dengan apa yang diharapkan untuk mendapatkan hasil yang akurat. Suatu kuesioner dapat dikatakan valid jika pertanyaan pada kuesioner mampu mengungkapkan sesuatu yang akan diukur oleh kuesioner tersebut.

Uji validitas dilakukan dengan membandingkan $\mathrm{R}$ hitung dari hasil output dengan $\mathrm{R}$ tabel yang penyelesaiannya dilakukan dengan menggunakan program SPSS 22, dimana jika $\mathrm{R}$ hitung > R tabel maka pertanyaan disetiap kuesioner tersebut dinyatakan valid, sebaliknya apabila $\mathrm{R}$ hitung $<\mathrm{R}$ tabel maka pertanyaan disetiap kuesioner tersebut dinyatakan tidak valid. Dalam penelitian ini dilakukan dengan uji signifikan yang membandingkan nilai $\mathrm{R}$ hitung dengan nilai $\mathrm{R}$ tabel untuk degree of freedom $(\mathrm{df})=\mathrm{n}-2$. Dalam hal ini $\mathrm{n}$ adalah jumlah sampel atau responden. Jadi, dalam penelitian ini $\mathrm{df}=100-$ 2 atau df $=98$ dengan alpha 5\% sehingga didapatkan hasil untuk $\mathrm{R}$ tabel $=0,1966$.

Berikut ini adalah hasil yang diberikan kepada 100 responden dengan memberikan 15 pertanyaan yang dibagi menjadi 2 variabel bebas dan 1 variabel terikat yaitu variabel kesadaran merek $\left(\mathrm{X}_{1}\right)$ sebanyak 5 pertanyaan, variabel kualitas produk $\left(\mathrm{X}_{2}\right)$ sebanyak 6 pertanyaan dan variabel kepuasan konsumen (Y) sebanyak 4 pertanyaan. Hasil uji validitas untuk penelitian ini dapat dilihat pada Tabel 1.

Tabel 1

Uji Validitas

\begin{tabular}{|c|c|c|c|c|c|}
\hline No. & Variabel & $\begin{array}{c}\text { Item } \\
\text { Pertanyaan }\end{array}$ & R Tabel & R Hitung & Keterangan \\
\hline \multirow{5}{*}{1.} & \multirow{5}{*}{$\begin{array}{c}\text { Kesadaran Merek } \\
\qquad\left(\mathrm{X}_{1}\right)\end{array}$} & KM1 & 0,1966 & 0,896 & Valid \\
\hline & & KM2 & 0,1966 & 0,834 & Valid \\
\hline & & KM3 & 0,1966 & 0,925 & Valid \\
\hline & & KM4 & 0,1966 & 0,906 & Valid \\
\hline & & KM5 & 0,1966 & 0,902 & Valid \\
\hline \multirow{6}{*}{2.} & \multirow{6}{*}{$\begin{array}{l}\text { Kualitas Produk } \\
\qquad\left(\mathrm{X}_{2}\right)\end{array}$} & KP1 & 0,1966 & 0,806 & Valid \\
\hline & & KP2 & 0,1966 & 0,918 & Valid \\
\hline & & KP3 & 0,1966 & 0,889 & Valid \\
\hline & & KP4 & 0,1966 & 0,905 & Valid \\
\hline & & KP5 & 0,1966 & 0,906 & Valid \\
\hline & & KP6 & 0,1966 & 0,851 & Valid \\
\hline \multirow{3}{*}{3.} & \multirow{3}{*}{$\begin{array}{c}\text { Kepuasan } \\
\text { Konsumen (Y) }\end{array}$} & KK1 & 0,1966 & 0,928 & Valid \\
\hline & & KK2 & 0,1966 & 0,899 & Valid \\
\hline & & KK3 & 0,1966 & 0,948 & Valid \\
\hline
\end{tabular}




\begin{tabular}{|l|l|l|l|l|l|}
\hline & & KK4 & 0,1966 & 0,915 & Valid \\
\hline
\end{tabular}

Sumber: Data primer diolah oleh SPSS (2020).

Berdasarkan Tabel 1 dapat dilihat bahwa masing-masing item pertanyaan memiliki $\mathrm{R}$ hitung positif dan lebih besar dari $\mathrm{R}$ tabel 0,1966. Maka dapat disimpulkan bahwa semua indikator dari kedua variabel $\mathrm{X}_{1}, \mathrm{X}_{2}$ dan $\mathrm{Y}$ dinyatakan valid.

\section{Hasil Uji Reliabilitas}

Ghozali (2013:52) mengatakan suatu kuesioner dikatakan reliabel atau handal jika jawaban responden terhadap pertanyaan tetap konsisten dari waktu ke waktu. Butir kuesioner dikatakan reliabel (layak) jika croncbach' alpha > 0,60 dan dikatakan tidak reliabel jika croncbach' alpha $<0,60$. Adapun hasil uji reliabilitas instrumen pertanyaan dengan menggunakan SPSS 22 dapat dilihat pada Tabel 2.

Tabel 2

\section{Uji Reliabilitas}

\begin{tabular}{|c|l|c|c|}
\hline No. & \multicolumn{1}{|c|}{ Variabel } & Nilai Croncbach' Alpha & Keterangan \\
\hline 1. & Kesadaran Merek & 0,936 & Reliabel \\
\hline 2. & Kualitas Produk & 0,941 & Reliabel \\
\hline 3. & Kepuasan Konsumen & 0,941 & Reliabel \\
\hline
\end{tabular}

Sumber: Data primer diolah oleh SPSS (2020).

Berdasarkan Tabel 2 dapat dilihat hasil uji reliabilitas menunjukan bahwa masingmasing variabel memiliki nilai croncbach alpha lebih besar dari 0,60. Maka dapat disimpulkan bahwa secara keseluruhan item pertanyaan sudah reliabel.

\section{Uji Asumsi Klasik}

\section{Hasil Uji Normalitas}

Penelitian ini melakukan uji normalitas data dengan melihat nilai signifikan di bagian Kolmogrov-Smirnov dari dalam tabel Test of Normality. Dalam uji normalitas, peneliti menggunakan nilai signifikan di bagian Kolmogrov-Smirnov karena data yang diuji lebih besar daripada 50. Hasil dari uji normalitas data dalam penelitian ini dapat dilihat pada Tabel 3.

Tabel 3

Uji Normalitas 
One-Sample Kolmogorov-Smirnov Test

\begin{tabular}{|ll|r|}
\hline & & $\begin{array}{c}\text { Unstandardized } \\
\text { Residual }\end{array}$ \\
\hline $\mathrm{N}$ & & 100 \\
Normal Parameters & a,b & Mean \\
& Std. Deviation & .0000000 \\
Most Extreme & Absolute & 2.67033782 \\
Differences & Positive & .116 \\
& Negative & .116 \\
Kolmogorov-Smirnov Z & -.084 \\
Asymp. Sig. (2-tailed) & 1.158 \\
\hline
\end{tabular}

a. Test distribution is Normal.

b. Calculated from data.

Sumber: Data primer diolah oleh SPSS (2020).

Berdasarkan hasil dari Tabel 3 dapat ditarik kesimpulan bahwa penelitian ini memiliki nilai normalitas sebesar 0,137 yang artinya lebih besar dari 0,05 maka data dalam penelitian ini sudah terdistribusi normal.

\section{Hasil Uji Multikolinearitas}

Sujarweni (2015:158) mengatakan Uji multikolinearitas bertujuan untuk mengetahui ada atau tidaknya variabel independen yang memiliki kemiripan antar variabel independen dalam suatu model. Kemiripan antar variabel independen akan mengakibatkan korelasi yang sangat kuat. Selain itu uji ini juga untuk menghindari kebiasaan dalam proses pengambilan keputusan mengenai pengaruh pada uji parsial masing-masing variabel independen terhadap variabel dependen. Suatu model regresi dikatakan multikolinearitas apabila nilai tolerance $<0,10$ dan nilai Variance Inflation Factor (VIF) $>10$. Hasil pengujian dapat dilihat pada Tabel 4.

\section{Tabel 4}

\section{Uji Multikolinearitas}




\section{Coefficients $^{\mathrm{a}}$}

\begin{tabular}{|c|c|c|c|c|c|c|c|}
\hline \multirow[t]{2}{*}{ Model } & \multicolumn{2}{|c|}{$\begin{array}{c}\text { Unstandardized } \\
\text { Coefficients }\end{array}$} & \multirow{2}{*}{$\begin{array}{c}\text { Standardize } \\
\mathrm{d} \\
\text { Coefficient } \\
\mathrm{s} \\
\text { Beta }\end{array}$} & \multirow[b]{2}{*}{$\mathrm{t}$} & \multirow[b]{2}{*}{ Sig. } & \multicolumn{2}{|c|}{$\begin{array}{c}\text { Collinearity } \\
\text { Statistics }\end{array}$} \\
\hline & B & Std. Error & & & & $\begin{array}{c}\text { Toleranc } \\
\mathrm{e}\end{array}$ & VIF \\
\hline 1 (Constant) & 7.299 & 1.389 & & 5.256 & .000 & & \\
\hline $\begin{array}{l}\text { Kesadaran } \\
\text { Merek }\end{array}$ & .221 & .061 & .326 & 3.640 & .000 & .821 & 1.218 \\
\hline $\begin{array}{l}\text { Kualitas } \\
\text { Produk }\end{array}$ & .238 & .056 & .384 & 4.278 & .000 & .821 & 1.218 \\
\hline
\end{tabular}

a. Dependent Variable: Kepuasan Konsumen

Sumber: Data primer diolah oleh SPSS (2020).

Berdasarkan hasil dari Tabel 4 menunjukan masing-masing variabel memiliki nilai tolerance $>0,10$ (dengan $X_{1}=0,821$ dan $\left.X_{2}=0,821\right)$. Maka dapat dikatakan bahwa diantara variabel tidak terjadi gejala multikolinearitas. Jika dilihat dari hasil perhitungan VIF, bahwa nilai VIF pada semua variabel $\mathrm{X}<10$ (dengan $\mathrm{X}_{1}=1,218 ; \mathrm{X}_{2}=1,218$ ). Jadi, dapat disimpulkan dalam penelitian ini tidak terjadi gejala multikolinearitas antara variabel independen dalam model regresi dan dapat digunakan dalam penelitian ini.

\section{Hasil Uji Heteroskedastisitas}

Uji heteroskedastisitas bertujuan untuk menunjukkan bahwa varians dari setiap variabel sama untuk semua pengamatan. Jika varians dari residual satu pengamatan ke pengamatan lain tetap, maka disebut homokedastisitas. Model regresi yang baik adalah terjadi homoskedastisitas atau dengan kata lain tidak terjadi heteroskedastisitas (Sarjono \& Julianita, 2011: 66). Metode uji yang digunakan adalah metode Glejser. Metode tersebut dilakukan dengan cara meregresikan variabel independen dengan nilai absolut residualnya (e) dimana:

1. Nilai probabilitas signifikansi $<0,05$, maka terjadi gejala heteroskedastisitas

2. Nilai probabilitas signifikansi $>0,05$, maka tidak terjadi gejala heteroskedastisitas.

Tabel 5

Uji Heteroskedastisitas Menggunakan Uji Glejser 


\section{Coefficients $^{\mathrm{a}}$}

\begin{tabular}{|c|c|c|c|c|c|c|}
\hline \multirow{2}{*}{\multicolumn{2}{|c|}{ Model }} & \multicolumn{2}{|c|}{$\begin{array}{c}\text { Unstandardized } \\
\text { Coefficients }\end{array}$} & \multirow{2}{*}{$\begin{array}{c}\begin{array}{c}\text { Standardized } \\
\text { Coefficients }\end{array} \\
\text { Beta }\end{array}$} & \multirow[t]{2}{*}{$\mathrm{T}$} & \multirow[t]{2}{*}{ Sig. } \\
\hline & & $\mathrm{B}$ & Std. Error & & & \\
\hline \multirow[t]{3}{*}{1} & (Constant) & .197 & .025 & & 7.801 & .000 \\
\hline & Kesadaran Merek & -.008 & .003 & -.589 & -2.811 & .068 \\
\hline & Kualitas Produk & .002 & .003 & .128 & .612 & .542 \\
\hline
\end{tabular}

a. Dependent Variable: Abs_Res

Sumber: Data primer diolah oleh SPSS (2020).

Berdasarkan hasil uji heteroskedastisitas pada Tabel 5 menunjukan bahwa semua variabel memiliki nilai signifikan lebih besar dari 0,05 yaitu variabel kesadaran merek $\left(\mathrm{X}_{1}\right)$ mempunyai nilai signifikan sebesar $0,068>0,05$, variabel kualitas produk $\left(\mathrm{X}_{2}\right)$ mempunyai nilai signifikan sebesar $0,542>0,05$. Dengan demikian dapat dikatakan bahwa semua variabel tidak terjadi heteroskedastisitas.

\section{Uji Regresi Linear Berganda}

Analisis regresi linear berganda bertujuan untuk mengetahui pengaruh kesadaran merek dan kualitas produk terhadap kepuasan konsumen pada toko Venka Gallery Banda Aceh. Selain itu untuk mengetahui sejauh mana besarnya pengaruh antara variabel bebas dan variabel terikat. Hasil pengolahan data analisis regresi berganda dengan menggunakan program SPSS 22 ditunjukkan dalam Tabel 6.

\section{Tabel 6}

\section{Hasil Uji Regresi Linear Berganda}

Coefficients $^{\mathrm{a}}$

\begin{tabular}{|c|c|c|c|c|c|}
\hline \multirow[t]{2}{*}{ Model } & \multicolumn{2}{|c|}{ Unstandardized Coefficients } & $\begin{array}{c}\text { Standardized } \\
\text { Coefficients }\end{array}$ & \multirow[b]{2}{*}{$\mathrm{t}$} & \multirow[b]{2}{*}{ Sig. } \\
\hline & B & Std. Error & Beta & & \\
\hline $1 \quad$ (Constant) & 7.299 & 1.389 & & 5.256 & .000 \\
\hline Kesadaran & .221 & .061 & .326 & 3.640 & .000 \\
\hline Merek & & & & & \\
\hline Kualitas Produk & .238 & .056 & .384 & 4.278 & .000 \\
\hline
\end{tabular}

a. Dependent Variable: Kepuasan Konsumen

Sumber: Data primer diolah oleh SPSS (2020).

Berdasarkan Tabel 6 yang diperoleh dari hasil pengolahan dengan menggunakan program SPSS maka diperoleh persamaan regresi linear berganda sebagai berikut:

$$
\begin{aligned}
& Y=a+b_{1} X_{1}+b_{2} X_{2}+e \\
& Y=7,299+0,221 X_{1}+0,238 X_{2}+e
\end{aligned}
$$


Model persamaan pada Tabel 6 dapat dijelaskan sebagai berikut:

1. Konstanta sebesar 7,299 menyatakan bahwa jika adanya variabel kesadaran merek $\left(\mathrm{X}_{1}\right)$ dan kualitas produk $\left(\mathrm{X}_{2}\right)$ maka akan meningkatkan kepuasan konsumen (Y) sebesar 7,299.

2. Koefisien regresi $X_{1}$

Koefisien regresi $X_{1}$ berpengaruh positif dan signifikan terhadap kepuasan konsumen. Nilai $b_{1}$ sebesar 0,221 berarti apabila variabel kesadaran merek $\left(\mathrm{X}_{1}\right)$ mengalami peningkatan sebesar 1 poin maka akan meningkat kepuasan konsumen (Y) terhadap pembelian produk pada toko Venka Gallery sebesar 0,221, dengan asumsi bahwa variabel bebas yang lain dari model regresi adalah tetap.

3. Koefisien regresi $\mathrm{X}_{2}$

Koefisien regresi $\mathrm{X}_{2}$ berpengaruh positif dan signifikan terhadap kepuasan konsumen. Nilai $b_{2}$ sebesar 0,238 berarti apabila variabel kualitas produk $\left(\mathrm{X}_{2}\right)$ mengalami peningkatan sebesar 1 poin maka akan meningkat kepuasan konsumen (Y) terhadap pembelian produk pada toko Venka Gallery sebesar 0,238, dengan asumsi bahwa variabel bebas yang lain dari model regresi adalah tetap.

\section{Uji Hipotesis}

\section{Hasil Uji Simultan (Uji F)}

Uji simultan digunakan untuk mengetahui apakah variabel independen secara simultan (bersama-sama) berpengaruh terhadap variabel dependen. Dalam penelitian ini, untuk mengetahui apakah variabel kesadaran merek dan kualitas produk secara simultan berpengaruh terhadap kepuasan konsumen. variabel independen dikatakan memiliki pengaruh terhadap variabel dependen apabila nilai $\mathrm{F}$ hitung $>\mathrm{F}$ tabel dan nilai probabilitas signifikansinya lebih kecil dari 0,05, maka Ha diterima dan Ho ditolak, artinya variabel kesadaran merek dan kualitas produk secara bersama-sama berpengaruh terhadap kepuasan konsumen. Sebaliknya, apabila nilai F hitung < F tabel dan nilai probabilitas signifikansinya lebih besar dari 0,05, maka Ha ditolak dan Ho diterima, artinya variabel kesadaran merek dan kualitas produk secara bersama-sama tidak berpengaruh terhadap kepuasan konsumen. Hasil dari uji simultan dalam penelitian ini dapat diliat pada Tabel 7.

Tabel 7

Uji Simultan (Uji F) 
ANOVA ${ }^{b}$

\begin{tabular}{|ll|r|r|r|r|r|}
\hline Model & & Sum of Squares & df & Mean Square & F & Sig. \\
\hline 1 & Regression & 242.596 & 2 & 121.298 & 27.241 & $.000^{\mathrm{a}}$ \\
& Residual & 431.914 & 97 & 4.453 & & \\
& Total & 674.510 & 99 & & & \\
\hline
\end{tabular}

a. Predictors: (Constant), Kualitas Produk, Kesadaran Merek

b. Dependent Variable: Kepuasan Konsumen

Sumber: Data primer diolah oleh SPSS (2020).

Berdasarkan Tabel 7 ditampilkan uji F yang dapat dipergunakan untuk memprediksi konstribusi aspek-aspek variabel kesadaran merek dan kualitas produk terhadap kepuasan konsumen. Dari perhitungan didapatkan nilai F hitung sebesar 27,241 dan F Tabel sebesar 3,94 yang diperoleh dari df =n-k-1= 100-2-1 = 97 (dimana $\mathrm{k}$ adalah jumlah variabel bebas dan $\mathrm{n}$ adalah jumlah sampel), karena nilai $\mathrm{F}$ hitung $>\mathrm{F}$ tabel atau 27,241 > 3,94 dan besar signifikan 0,000 < 0,05, maka hal ini menunjukkan bahwa Ho ditolak dan Ha diterima yang artinya variabel independen atau kesadaran merek $\left(\mathrm{X}_{1}\right)$ dan kualitas produk $\left(\mathrm{X}_{2}\right)$ secara bersama-sama berpengaruh signifikan terhadap variabel kepuasan konsumen (Y).

\section{Hasil Uji Parsial (Uji t)}

Uji parsial dilakukan untuk mengetahui apakah variabel independen secara individual (parsial) berpengaruh terhadap variabel dependen. Uji parsial atau uji t pada dasarnya menunjukkan seberapa jauh satu variabel independen secara individu dalam menerangkan variasi variabel dependen (Ghozali, 2013:178). Dari perhitungan didapatkan nilai t tabel sebesar 1,98447 yang diperoleh dari $\mathrm{df}=\mathrm{n}-\mathrm{k}=100-2=98$ (dimana $\mathrm{k}$ adalah jumlah variabel bebas dan $\mathrm{n}$ adalah jumlah sampel). Pengujian ini memiliki ketentuan-ketentuan, yaitu:

1. Jika probabilitas (signifikansi) $<0,05$ atau t hitung $>\mathrm{t}$ tabel, maka Ho ditolak dan Ha diterima yang berarti variabel bebas dapat menerangkan variabel terikat secara individual.

2. Jika probabilitas (signifikansi) $>0,05$ atau $t$ hitung $<\mathrm{t}$ tabel maka Ho diterima dan Ha ditolak yang berarti variabel bebas tidak dapat menerangkan variabel terikatnya secara individual.

Tabel 8

Uji Parsial (Uji t) 
Coefficients $^{\mathrm{a}}$

\begin{tabular}{|l|r|r|r|r|r|}
\hline \multirow{2}{*}{ Model } & \multicolumn{2}{|c|}{$\begin{array}{c}\text { Unstandardized } \\
\text { Coefficients }\end{array}$} & $\begin{array}{c}\text { Standardized } \\
\text { Coefficients }\end{array}$ & & \\
\cline { 2 - 4 } & \multicolumn{1}{|c|}{$\mathrm{B}$} & \multicolumn{1}{|c|}{ Std. Error } & \multicolumn{1}{c|}{ Beta } & \multicolumn{1}{c|}{$\mathrm{t}$} & \multicolumn{1}{c|}{ Sig. } \\
\hline 1 (Constant) & 7.299 & 1.389 & & 5.256 & .000 \\
Kesadaran & .221 & .061 & .326 & 3.640 & .000 \\
Merek & & & & & \\
Kualitas Produk & .238 & .056 & .384 & 4.278 & .000 \\
\hline
\end{tabular}

a. Dependent Variable: Kepuasan Konsumen

Sumber: Data primer diolah oleh SPSS (2020).

Berdasarkan Tabel 8, diperoleh nilai t hitung kesadaran merek $\left(\mathrm{X}_{1}\right)$ sebesar 3,640 yang lebih besar dari tabel sebesar 1,98447 dengan nilai probabilitas signifikansi $0,000<0,05$, artinya variabel kesadaran merek secara parsial berpengaruh positif dan signifikan terhadap kepuasan konsumen. Maka dalam penelitian ini Ho ditolak dan Ha diterima yang artinya kesadaran merek berpengaruh positif dan signifikan terhadap kepuasan konsumen.

Nilai thitung variabel kualitas produk $\left(\mathrm{X}_{2}\right)$ sebesar 4,278 yang lebih besar dari $\mathrm{t}$ tabel 1,98447 dengan nilai probabilitas signifikansi $0,000<0,05$, artinya variabel kualitas produk secara parsial berpengaruh positif dan signifikan terhadap kepuasan konsumen. Maka dalam penelitian ini Ho ditolak dan Ha diterima yang artinya kualitas produk berpengaruh positif dan signifikan terhadap kepuasan konsumen.

\section{Hasil Uji Koefisien Determinasi $\left(\mathbf{R}^{\mathbf{2}}\right)$}

Uji koefisien determinasi digunakan untuk mengukur sejauh mana tingkat hubungan antara variabel dependen dengan independen atau sebaliknya sejauh mana kontribusi variabel independen mempengaruhi. Hasil uji determinasi $\left(\mathrm{R}^{2}\right)$ dapat diliat pada Tabel 9.

\section{Tabel 9}

\section{Uji Koefisien Determinasi $\left(\mathbf{R}^{2}\right)$}

\section{Model Summary}

\begin{tabular}{|l|r|r|r|r|}
\hline $\begin{array}{l}\text { Mode } \\
1\end{array}$ & \multicolumn{1}{|c|}{$\mathrm{R}$} & R Square & $\begin{array}{c}\text { Adjusted R } \\
\text { Square }\end{array}$ & $\begin{array}{l}\text { Std. Error of } \\
\text { the Estimate }\end{array}$ \\
\hline 1 & $.600^{\mathrm{a}}$ & .360 & .346 & 2.110 \\
\hline
\end{tabular}

a. Predictors: (Constant), Kesadaran Merek, Kualitas

Produk

b. Dependent Variable: Kepuasan Konsumen

Sumber: Data primer diolah oleh SPSS (2020).

Berdasarkan Tabel 9 menunjukkan bahwa nilai koefisien determinasi $\left(\mathrm{R}^{2}\right)$ sebesar 0,360. Hal ini berarti 36,0 \% variabel dependen berupa kepuasan konsumen dalam 
membeli produk di toko Venka Gallery dapat dipengaruhi oleh variabel kesadaran merek dan kualitas produk sedangkan sisanya sebesar 64,0 \% dipengaruhi oleh variabel lain yang tidak disertakan dalam penelitian ini.

\section{Pengaruh Kesadaran Merek terhadap Kepuasan Konsumen}

Berdasarkan Tabel 8 dapat diketahui bahwa kesadaran merek memiliki nilai t hitung sebesar 3,640 yang lebih besar dari t tabel sebesar 1,98447 dengan nilai probabilitas signifikansi $0,000<0,05$. Hasil dari nilai tersebut dapat disimpulkan bahwa variabel kesadaran merek memiliki pengaruh yang positif dan signifikan terhadap kepuasan konsumen. Hal ini menunjukkan bahwa konsumen toko Venka Gallery sudah mengenali akan hadirnya merek Venka sebagai salah satu merek busana muslim, konsumen yang sadar akan merek biasanya akan memiliki perasaan bangga terhadap suatu merek yang merupakan salah satu cerminan kepuasan. Konsumen yang sadar dengan merek maka dengan mudah mengenali dan juga mengingat merek di benaknya, kemudian akan menggunakan merek tersebut dan akan merasakan kepuasan setelah menggunakannya. Produk dengan merek Venka sudah sesuai dengan tata cara berpakaian dalam Islam yaitu menutup aurat.

Dari hasil analisis linear berganda pada Tabel 8 dapat dilihat bahwa kesadaran merek memiliki pengaruh sebesar 0,221 terhadap kepuasan konsumen. Hal ini berarti jika kesadaran merek mengalami peningkatan sebesar 1 poin maka diperkirakan dapat meningkatkan kepuasan konsumen sebesar 0,221 dengan asumsi bahwa variabel bebas yang lain dari model regresi adalah tetap. Maka dengan hal itu dapat disimpulkan bahwa kepuasan konsumen dipengaruhi oleh kesadaran merek. Hasil dari penelitian ini sejalan dengan penelitian yang dilakukan oleh Utama (2014), Hanafi (2015), Ramadhani dan Harry (2016), Diah dan Saryadi (2017) dan Chotijah (2018) yang mengatakan bahwa kesadaran merek berpengaruh positif dan signifikan terhadap kepuasan konsumen.

\section{Pengaruh Kualitas Produk terhadap Kepuasan Konsumen}

Berdasarkan Tabel 8 dapat diketahui bahwa kualitas produk memiliki nilai t hitung sebesar 4,278 yang lebih besar dari t tabel sebesar 1,98447 dengan nilai probabilitas signifikansi $0,000<0,05$. Hasil dari nilai tersebut dapat disimpulkan bahwa variabel kualitas produk memiliki pengaruh yang positif dan signifikan terhadap kepuasan konsumen. Hal ini menunjukkan bahwa produk dari merek Venka sudah memiliki kualitas yang baik, harga yang sesuai dengan kualitasnya dan sesuai dengan harapan konsumen sehingga terciptanya kepuasan bagi konsumen. Demi memuaskan konsumen tentunya pihak toko Venka Gallery memberikan kualitas yang baik terhadap produk yang dijualnya sehingga tidak menimbulkan rasa kecewa dari diri konsumen dan konsumen akan merasa puas setelah membeli dan menggunakan produk tersebut. Produk yang dijual pada toko Venka Gallery sudah memenuhi tata cara berpakaian dalam Islam seperti tidak membentuk tubuh, tidak ketat, bahan yang digunakan juga tidak tipis sehingga tidak menerawang ketika dipakai.

Dalam Islam kualitas dipandang sebagai sebuah konsep secara totalitas. Perbuatan 
yang mengabaikan kualitas merupakan perbuatan yang sia-sia, demikian juga pada produk yang mengabaikan kualitasnya orang akan berfikir berulang-ulang untuk membelinya. Praktis bisnis yang mengedepankan kualitas sebagai daya saing berbisnis tidak bertentangan dengan ajaran Islam, karena pada hakikatnya meningkatkan kualitas produk dan jasa agar lebih baik merupakan bagian dari kejujuran dan kebenaran dalam berbisnis sehingga menimbulkan keikhlasan bagi masing-masing dalam bertransaksi bisnis antara penjual dan pembeli. Kualitas adalah suatu upaya untuk menghasilkan segala sesuatu yang terbaik, sekaligus meningkatkan serta menjamin keberlangsungan dan kemajuannya. Sebagaimana dalam Firman Allah dalam Al-Qur'an surah An-Naml: 88 sebagai berikut:

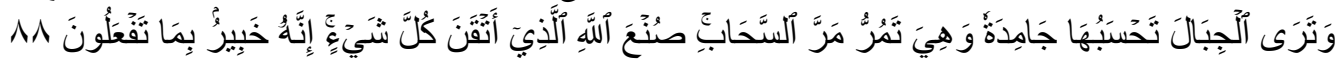
Artinya: "Dan kamu lihat gunung-gunung itu, kamu sangka dia tetap di tempatnya, padahal ia berjalan sebagai jalannya awan. (Begitulah) perbuatan Allah yang membuat dengan kokoh tiap-tiap sesuatu, sesungguhnya Allah Maha mengetahui apa yang kamu kerjakan”. (Q.S An-Naml [27]: 88).

Berdasarkan tafsir Al-Qur'an karangan Shihab (2012:286) maksud ayat diatas menjelaskan bahwa dalam memproduksi suatu barang harus diselesaikan dengan kualitas yang sempurna dan sebaik-baiknya, karena Allah SWT sudah menciptakan semua yang ada di langit dan di bumi dengan kualitas yang sempurna. Jika pada suatu produk maka dapat dikatakan sebagai produk yang memiliki kualitas yang baik.

Sesuai dengan teori tersebut, dapat disimpulkan bahwa setiap perusahaan baik bisnis produk maupun jasa harus memberikan kualitas yang baik, begitu pula pada toko Venka Gallery Banda Aceh sudah memberikan produk yang berkualitas baik serta dapat memberikan manfaat kepada orang lain serta produk yang dijual sudah sesuai dengan tata cara berpakaian dalam Islam yaitu mampu menutup aurat sehingga dapat terhindar dari hal-hal yang mengandung mudharat. Dari hasil analisis linear berganda pada Tabel 8 dapat dilihat bahwa kualitas produk memiliki pengaruh sebesar 0,238 terhadap kepuasan konsumen. Hal ini berarti jika kualitas produk mengalami peningkatan sebesar 1 poin maka diperkirakan dapat meningkatkan kepuasan konsumen sebesar 0,238 dengan asumsi bahwa variabel bebas yang lain dari model regresi adalah tetap. Dapat disimpulkan bahwa kepuasan konsumen dipengaruhi oleh kualitas produk.

Hasil penelitian ini mendukung penelitian yang dilakukan oleh Purnamasari (2015), Rachel (2019), Roselina dan Asih (2019) yang mengatakan bahwa pengaruh kualitas produk terhadap kepuasan konsumen adalah positif dan signifikan, namun hasil penelitian ini tidak mendukung hasil penelitian yang dilakukan oleh Haris dan Henny (2018) yang mendapatkan hasil bahwa kualitas produk berpengaruh negatif dan tidak signifikan terhadap kepuasan konsumen, selanjutnya hasil penelitian ini juga tidak mendukung hasil dari penelitian yang dilakukan oleh Diana (2017) yang mendapatkan hasil bahwa kualitas produk tidak berpengaruh terhadap kepuasan konsumen. 


\section{Pengaruh Kesadaran Merek dan Kualitas Produk Secara Bersama-sama terhadap Kepuasan Konsumen}

Berdasarkan Tabel 7 diketahui bahwa variabel independen memiliki pengaruh yang signifikan terhadap kepuasan konsumen. Hal ini dibuktikan dengan hasil uji $\mathrm{F}$ yang memiliki nilai $\mathrm{F}$ hitung lebih besar dari $\mathrm{F}$ tabel atau 27,241 > 3,94, dan nilai signifikan $0,000<0,05$ sehingga dapat disimpulkan bahwa kesadaran merek dan kualitas produk memiliki pengaruh secara signifikan terhadap kepuasan konsumen.

Untuk menguji pengaruh secara bersama-sama dapat juga dilakukan dengan menggunakan uji koefisien determinasi $\left(\mathrm{R}^{2}\right)$. Apabila nilai $\mathrm{R}^{2} \neq 0$, maka variabel independen secara bersama-sama berpengaruh terhadap variabel dependen. Berdasarkan Tabel 9, nilai $\mathrm{R}^{2}$ sebesar 0,360 atau $\neq 0$, maka hal ini menunjukkan bahwa variabel kesadaran merek dan kualitas produk berpengaruh terhadap kepuasan konsumen pada toko Venka Gallery Banda Aceh. Penelitian ini sejalan dengan penelitian yang dilakukan oleh Darmawan (2019) yang menemukan bahwa kesadaran merek dan kualitas produk secara simultan (bersama-sama) berpengaruh secara positif dan signifikan.

\section{Kesimpulan}

Berdasarkan hasil penelitian dan pembahasan yang diperoleh, maka dapat dikatakan kesimpulan jawaban dari perumusan masalah yaitu sebagai berikut:

1. Berdasarkan hasil pengujian yang dilakukan secara simultan diperoleh hasil bahwa variabel kesadaran merek dan kualitas produk secara bersama-sama berpengaruh positif dan signifikan terhadap kepuasan konsumen pada toko Venka Gallery Banda Aceh dengan nilai $\mathrm{F}$ hitung lebih besar dari $\mathrm{F}$ tabel atau 27,241 > 3,94 dan nilai signifikan $0,000<0,05$.

2. Berdasarkan hasil pengujian yang dilakukan terhadap variabel kesadaran merek menunjukkan bahwa terdapat pengaruh positif dan signifikan terhadap kepuasan konsumen toko Venka Gallery dengan nilai t hitung sebesar 3,640 yang lebih besar dari t tabel sebesar 1,98447 dengan nilai probabilitas signifikansi $0,000<0,05$. Hal ini menunjukkan bahwa konsumen toko Venka Gallery sudah mengenali akan hadirnya merek Venka sebagai salah satu merek busana muslim, konsumen yang sadar akan merek biasanya akan memiliki perasaan bangga terhadap suatu merek yang merupakan salah satu cerminan kepuasan. Konsumen yang sadar dengan merek maka dengan mudah mengenali dan juga mengingat merek di benaknya, kemudian akan menggunakan merek tersebut dan akan merasakan kepuasan setelah menggunakannya.

3. Berdasarkan hasil pengujian yang dilakukan terhadap variabel kualitas produk menunjukkan bahwa terdapat pengaruh yang positif dan signifikan terhadap kepuasan konsumen pada toko Venka Gallery dengan nilai t hitung sebesar 4,278 yang lebih besar dari t tabel sebesar 1,98447 dengan nilai probabilitas signifikansi $0,000<0,05$. Hal ini menunjukkan bahwa tentunya pihak toko Venka Gallery telah memberikan kualitas yang baik terhadap produk yang dijualnya sehingga tidak 
menimbulkan rasa kecewa dari diri konsumen, maka oleh karena itu akan terciptanya kepuasan bagi konsumen setelah membeli dan menggunakan produk tersebut. Produk yang dijual pada toko Venka Gallery sudah memenuhi tata cara berpakaian dalam Islam seperti tidak membentuk tubuh, tidak ketat, bahan yang digunakan juga tidak tipis sehingga tidak menerawang ketika dipakai. 
Pengaruh Kesadaran Merek Dan Kualitas Produk Terhadap Kepuasan Konsumen

\section{Bibliografi}

Aaker, D. (2013). Manajemen Pemasaran Strategis. Jakarta: Salemba Empat

Assauri, S. (2013). Manajemen Pemasaran: Dasar, Konsep dan Strategi. Jakarta: PT. Grafindo Persada

Asy- Syatibi, A. I. (2003). Al-Muwafaqat Fi Ushul Asy-Syari'ah. Jilid 2. Beirut: Dar AlKutub Al-'Ilmiyyah.

Baetie, D. (2018). Pengaruh Kualitas Pelayanan Terhadap Kepuasan Tamu di Hotel Niagara Parapat Provinsi Sumatera Utara. Jurnal JOM FISIP, 5 (1), 1-13.

Chotijah, S. H. (2018). Pengaruh Ekuitas Merek Terhadap Kepuasan Konsumen Kosmetik Wardah Pada Mahasiswa di Kota Malang. Malang: Universitas Islam Negeri Maulana Malik Ibrahim.

Darmawan, D. (2019). Kualitas Produk, Kesadaran Merek dan Harga Serta Pengaruhnya Terhadap Kepuasan Pelanggan. Jurnal Administrasi Bisnis, 8 (2), 75-88.

Diah, T., U dan Saryadi. (2017). Pengaruh Kesadaran Merek, Persepsi Kualitas dan Asosiasi Merek Terhadap Loyalitas Merek Melalui Kepuasan Konsumen Sebagai Variabel Intervening Pada Pengguna IM3 (Studi Pada Mahasiswa S1 Universitas Diponegoro Semarang). Semarang: Universitas Diponegoro.

Diana, I., M. (2017). Pengaruh Kualitas Poduk, Kualitas Pelayanan dan Harga Terhadap Kepuasan Konsumen. Yogyakarta: Universitas Sanata Dharma.

Frinces, H. (2011). Be An Entrepreneur. Yogyakarta: Graha Ilmu.

Gaspersz, V. (2008). Total Quality Management. Jakarta: Gramedia Pustaka Utama.

Ghozali, I. (2013). Aplikasi Analisis Multivariate Dengan Program IBM SPSS. Edisi 7. Semarang: Universitas Diponegoro.

Hanafi, A. F. (2015). Pengaruh Brand Equity Mobil Toyota Yaris Terhadap Kepuasan Konsumen (Studi Pada Pengguna Mobil Toyota Yaris di Yogyakarta). Yogyakarta: Universitas Muhammadiyah Yogyakarta.

Haris, D \& Henny, W. (2018). Kualitas dan Desain Produk Dalam Meningkatkan Kepuasan dan Loyalitas Konsumen (Studi Kasus Baju Dagadu Yogyakarta). Jurnal Upajiwa Dewantara, 2 (2), 125-139.

Kotler, P \& Amstrong, G. (2012). Prinsip-Prinsip Manajemen. Alih Bahasa Bob Sabran. Edisi 13, Jilid 1. Jakarta: Erlangga

Lajnah Pentashihan Mushaf Al-Qur'an. (2014). Tafsir Al-Qur'an Tematik. Jilid 1. Jakarta: Kamil Pustaka.

Lupiyoadi, R. (2013). Manajemen Pemasaran Jasa: Berbasis Kompetensi. Jakarta: Salemba Empat.

Noor, J. (2011). Metodologi Penelitian: Skripsi, Tesis, Disertasi, dan Karya Ilmiah. Jakarta: Kencana.

Prawirosentono, S. (2002). Filosofi Baru Tentang Manajemen Mutu Terpadu Abad 21 Studi Kasus dan Analisis. Jakarta: Bumi Aksara.

Purnamasari, Y. I. (2015). Pengaruh Kualitas Produk dan Harga Terhadap Kepuasan 
Konsumen Produk M2 Fashion Online di Singaraja Tahun 2015. Jurnal Jurusan Pendidikan Ekonomi, 5 (1), 1-12.

Pusat Pengkajian dan Pengembangan Ekonomi Islam (P3EI). (2008). Universitas Islam Indonesia Yogyakarta Atas Kerjasama Dengan Bank Indonesia: Ekonomi Islam. Jakarta: PT Raja Grapindo.

Rachel, F., S. (2019). Pengaruh Kualitas Produk dan Harga Terhadap Kepuasan Konsumen Pada Toko Sepatu Bata MTC Giant Panam Pekanbaru. JOM FISIP, 6 (2), 1-14.

Ramadhani, R \& Harry, S. (2016). Analisis Pengaruh Harga, Kualitas Produk dan Kesadaran Merek Terhadap Kepuasan Pelanggan dan Implikasinya Terhadap Loyalitas Pelanggan (Studi Pada Mahasiswa Pengguna Kartu Simpati di Wilayah Kota Semarang). Diponegoro Journal Of Management, 5 (3), 1-10.

Rivai, V. (2012). Islamic Business and Economic Ethics. Jakarta: Bumi Aksara.

Roselina, M., A \& Asih, N. (2019). Analisis Pengaruh Kualitas Produk, Kualitas Pelayanan dan Promosi Terhadap Kepuasan Konsumen Elsa Hijab Semarang. Majalah Ilmiah Solusi, 17 (3), 221-234.

Rozalinda. (2014). Ekonomi Islam Teori dan Aplikasinya Pada Aktivitas Ekonomi. Jakarta: PT Raja Grafindo Persada.

Sadat, A. M. (2009). Brand Belief: Sttategi Membangun Merek Berbasis Keyakinan. Jakarta: Salemba Empat.

Sarjono, H \& Julianita, W. (2011). SPSS VS LISREL: Sebuah Pengantar Aplikasi Untuk Riset. Jakarta: Salemba Empat.

Shihab, M. Q. (2012). Tafsir Al-Mishbah Pesan, Kesan dan Keserasian Al-Qur'an. Jakarta: Lentera Hati.

Sugiyono. (2018). Metode Penelitian Kuantitatif, Kualitatif dan R\&D. Bandung: Alfabeta.

Sujarweni, V.W. (2015). Statistik Untuk Bisnis dan Ekonomi. Yogyakarta: Pustaka Baru Press.

Sulfianto, A. (2010). Alqur'an dan Kepuasan Pelanggan Bank Syariah. Academia Edu.

Sunarto. (2006). Pengantar Manajemen Pemasaran. Yogyakarta: Press.

Supranto. (2012). Metode Riset Aplikasinya dalam Pemasaran. Jakarta: PT Rineka Cipta.

Suwarman, U. (2014). Perilaku Konsumen: Teori dan Penerapnnya dalam Pemasaran. Jakarta: PT Ghalia Indonesia.

Tjiptono, F. (2008). Strategi Pemasaran. Edisi 3. Yogyakarta: Andi Offset.

Utama, B. A. (2014). Pengaruh Ekuitas Merek Terhadap Kepuasan Pelanggan (Studi Pada Toko Roti Shereen Cakes \& Bread di Bandar Lampung). Universitas Lampung. 